\title{
Pendekatan Strategik Mengelola Perubahan Organisasi
}

\section{Retno Wulandari*}

\begin{abstract}
If businesses are to survive, leaders must have anticipatory capability, flexibility, and adaptability when adjusting to major changes. But, it is not easy to make change successfully because of many forces facing by leaders. Change will always cause discomfort and dislocation for member of organization. This paper focuses on strategic element and practical solution to ensure implementation success. Developing readiness for planning will reduce participant unprepared to deal with change. Furthermore, leaders must recognize, guide, and support people in their organization to make change initiative.
\end{abstract}

Keywords: change, forces, strategic element, readiness for planning

\section{Pendahuluan}

Kondisi perekonomian, sosial, dan trend teknologi sangat besar dampaknya terhadap kehidupan usaha. Banyak perusahaan telah melakukan upaya-upaya seperti: menciptakan kultur organisasi baru, melakukan rightsizing dan downsizing, menerapkan sistem informasi baru, menerapkan teknologi baru, maupun mengimplementasikan metode manufaktur baru (Heifetz, 1996).Upaya-upaya perubahan tersebut dilakukan oleh para manajer perusahaan untuk mempertahankan perusahaan dan mencoba memenuhi berbagai tuntutan eksternal dan internal organisasi.

Menurut Goldberg dan Sifonis (1994), jika perusahaan berupaya untuk survive, leader harus memiliki kemampuan antisipasi, kemampuan beradaptasi, dan fleksibel sehingga dapat membuat perbedaan penting ketika menyesuaikan diri dengan perubahan-perubahan besar. Ketidakberhasilan manajer mengelola perusahaan biasanya akibat kegagalannya mengantisipasi dan mengakomodasi perkembangan lingkungan, khususnya perubahan teknologi dan juga perubahanperubahan yang diciptakan oleh teknologi.

- Dosen STIE YKPN Yogyakarta 
Di sisi lain, upaya-upaya perubahan seringkali juga tidak dapat berjalan dengan baik juga karena para manajer sering dihadapkan pada penolakanpenolakan karyawan atas perubahan yang dilakukan, padahal perubahan tersebut diyakini para manajer sangat penting bagi kelangsungan hidup perusahaan. Hampir semua perusahaan dihadapkan pada penolakan dan potential chaos pada setiap upaya perubahan. Masalah-masalah tersebut sangatlah kompleks dan juga penuh tantangan.

Mengingat banyaknya ketidakberhasilan proses transformasi tersebut, akhirnya muncul pertanyaan mengapa usaha-usaha transformasi tersebut gagal. Beberapa ahli berpendapat bahwa tampaknya ada gap antara ide-ide perubahan dengan pemecahan masalah-masalah tersebut. Paper ini mencoba membahas bagaimana upaya-upaya perubahan organisasi untuk menuju organisasi yang sukses.

\section{Dorongan Perubahan}

Tren ekonomi, politik, sosial, dan teknologi berdampak besar pada bisnis (Goldberg and Sifonis, 1994). Walter Writson, CEO Citicorp mengatakan bahwa "Perekonomian nasional tidak dapat dipahami kecuali memahami hubungan dengan perekonomian negara lainnya". Keterkaitan perekonomian antar negara mendorong koordinasi internasional akan kebijakan perekonomian nasional dan semua itu akan berdampak pada setiap perusahaan. Perubahan dramatis terjadi juga pada kehidupan politik negara. Sistem pendidikan juga masih gagal memberikan tenaga kerja terlatih dan empowered. Selain itu, teknologi tidak saja membantu organisasi, tetapi juga mengubah bagaimana struktur organisasi agar sesuai dengan kebutuhan yang ada. Perkembangan teknologi sendiri sangat cepat dan selalu akan berubah.

Selalu ada pernyataan, "berubah atau mati". Pernyataan ini seringkali terdengar di setiap bisnis dimanapun. Para eksekutif tahu benar bahwa perusahaan harus cepat, fieksibel, responsif, elastis, dan kreatif untuk bisa berlanjut. Para eksekutif tidak hanya menjadikan keberlangsungan organisasi dalam jangka pendek tetapi juga membangunnya untuk masa yang akan datang. Suatu tugas yang membutuhkan pemikiran baru dan holistik.

Studi pada perusahaan manufaktur dalam melakukan perubahan organisasi menunjukkan bahwa dorongan perubahan organisasinya dipicu oleh tuntutan customer, persaingan usaha, dan ekspektasi organisasi untuk menghasilkan produk berkualitas (Bonvilian,1997). Lingkungan eksternal organisasi telah tumbuh sangat cepat, pengembangan organisasi telah didorong untuk meningkatkan skala besar dan praktik-praktik strategik. Pengembangan organisasi strategik ini sebagai usaha untuk meningkatkan organisasi dalam hubungannya dengan lingkungannya dan 

yang besar ini tidak dapat diimplementasikan dengan cepat. Perubahan kultur orgạisasi yang diperlukan untuk bisa menyesuaikan dengan lingkungan bisa meñcapai minimum 6 sampai 15 tahun dengan usaha yang solid (Head, 2006).

\section{Teori Force-Field}

Menurut teori force-field Kurt Lewin, setiap perilaku adalah hasil keseimbangan antara driving forces (tekanan-tekanan yang mendorong) dan restraining forces (tekanan-tekanan yang menghambat). Tekanan mendorong dari satu sisi sedangkan tekanan menghambat dari sisi yang lain. Kinerja yang muncul kemudian adalah hasil dari rekonsiliasi antara dua tekanan tadi (Stoner, et.al., 1995). Perkembangan organisasi tentu saja ditentukan oleh banyaknya dorongandorongan untuk melakukan perubahan, tetapi di sisi lain sangat penting jụga untuk menyadari adanya dorongan-dorongan dari arah yang berlawanan yang menjadikan organisasi dalam kondisi tetap sama. Dorongan yang berlawanan ini disebut sebagai stabilitas atau status quo.

Model Lewin mengingatkan kita bahwa perilaku terbentuk dari berbagai sebab, bukan hanya dari satu sebab saja. Program planned change Lewin diarahkan untuk menghilangkan hambatan-hambatan dan memperkuat atau menciptakan driving forces yang ada dalam organisasi. Diagram force-field dapat dilihat pada gambar 1 .

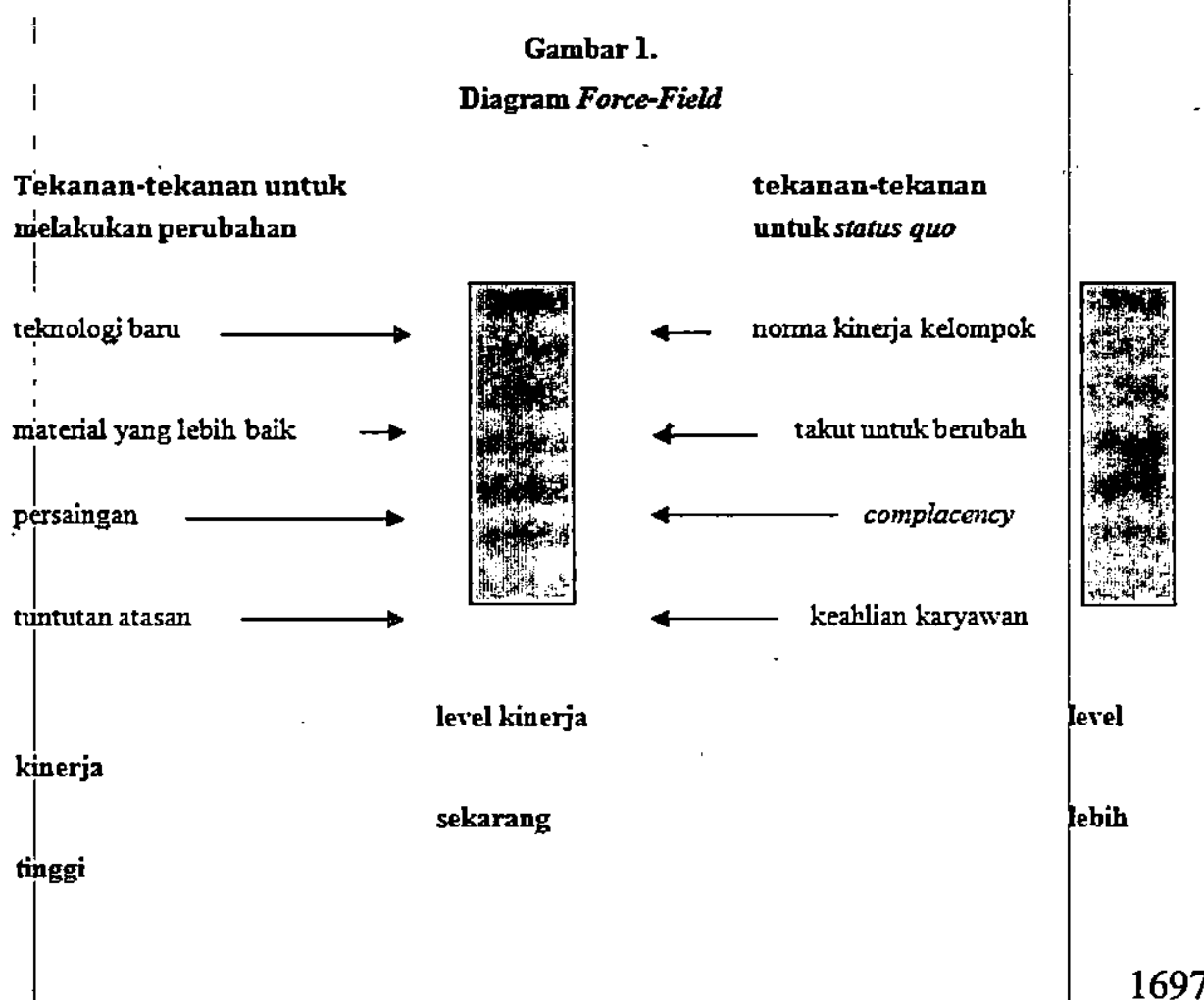


Faktor-faktor penghambat ini merupakan faktor-faktor yang menyebabkan organisasi dalam kondisi tetap sama dan merupakan sumber-sumber potensial penolakan terhadap setiap perubahan yang direncanakan. Apabila para manajer dapat mengurangi tekanan-tekanan ini, mereka akan mempunyai kesempatan lebih baik lagi untuk menyelesaikan perubahan. Sumber resistensi diidentifikasi sebagai berikut: kultur organisasi, minat setiap individu, dan persepsi setiap individu terhadap strategi dan tujuan organisasi (Hopen. 2004; Stoner, et.al., 1995).

Kultur merupakan faktor dasar yang mengarahkan perilaku karyawan. Karyawan tetap bekerja dalam organisasi karena pekerjaan menolong mereka untuk memenuhi tujuan hidup mereka. Kepribadian, sikap, dan keyakinan mereka juga telah menyesuaikan dengan kultur organisasi yang ada. Oleh karenanya, mereka akan merasa terancam oleh berbagai upaya perubahan dalam organisasi dan menganggap cara yang sudah mereka lakukan sudah baik.

Meskipun karyawan bekerja untuk mencapai tujuan organisasi, karyawan juga memperhatikan kepentingan mereka sendiri. Mereka mengharapkan gaji yang cukup, kondisi kerja yang memuaskan, keamanan kerja, serta menginginkan power dan prestis atas pekerjaan yang telah mereka lakukan. Ketika perubahan dilakukan, karyawan dihadapkan pada periode penyesuaian yang tidak menyenangkan dengan struktur organisasi baru ataupun pekerjaan yang didisain ulang.

Tujuan dan strategi sangat menentukan selama proses mengorganisasikan dan mengkoordinasikan upaya-upaya organisasi. Misi dapat mengarahkan perilaku kerja. Seringkali karyawan juga tidak memahami kebutuhan tujuan baru karena mereka tidak mempunyai informasi yang sama dengan informasi yang dimiliki oleh manajer

\section{Bagaimana Mengelola Perubahan?}

Beberapa cara strategik untuk mengelola perubahan telah dikembangkan baik pada perencanaan maupun pelaksanaan usaha-usaha perubahan komprehensif. Menurut Heifetz dan Halle (1996), untuk mengelola perubahan organisasi diperlukan strategic tools, yaitu menentukan Formula Perubahan dan Siklus Perubahan. Formula Perubahan membantu untuk menjawab pertanyaan-pertanyaan seperti:

a. Apa driving forces dalam setiap upaya perubahan?

b. Apakah cukup dorongan-dorongan tersebut untuk menjadikan perubahan seperti yang diinginkan?

c. Apakah organisasi siap?

Semua driving forces ini harus cukup ada untuk mengatasi penolakanpenolakan di setiap proses perubahan. Seringkali driving forces tidak kuat sehingga 
harus diperkuat agar perubahan dapat berhasil. Jika driving forces tidak kuat akan menyebabkan kondisi akan tetap sama seperti semula.

Sebagai contoh permasalahan sederhana sebagai berikut. Ketikalkita pergi ke dokter untuk pengecekan fisik, dokter akan memberikan diagnosenya atas hasil pemeriksaan. Dokter akan mengatakan ada penyakit di tubuh dan bisa suatu waktu menjadi parah. Tentu saja, berita ini tidak menyenangkan. Ada perubahan yang harus dilakukan. Kita akan menentukan target, yaitu tujuan pribadi atas perubahan yang akan dilakukan, misal: menurunkan berat badan, berhenti merokok, makan makanan yang sehat, dan lain-lain. Ini adalah visi, yaitu apa yang harus dilakukan. Selanjutnya adalah harus memilih metode atau cara, misal: apakah ikut kelas khusus, mengubah kebiasaan makan, ikut program asuransi, dan lain-lain. Ini adalah proses, yaitu bagaimana cara melaksanakan. Berikutnya, kita harus mempraktikkannya semua hal tersebut. Dalam praktik seringkali muncul alasanalasan untuk tidak melakukan, misalnya: kita datang terlambat pada kelas khusus, meninggalkan kelas, memesan makanan yang sebenarnya dilarang, merasa upaya yang dilakukan hanya sebagai kewajiban, dan lain-lain. Ini disebut sebagai resistensi atau menolak untuk melakukan perubahan tersebut.

Analogi dengan contoh tadi, maka perusahaan perlu membuat Formula Perubahan sebagai berikut: melihat latar belakang pada suatu kasus, mengaplikasikan formula perubahan sebagai alat penilaian, mendiskusikan faktorfaktor yang hilang atau melemahkan, mencari rekomendasi, apa yang telah dikẹrjakan, dan mengkaitkan dengan kondisi aktual yang terjadi.

Strategic tool berikutnya adalah Siklus Perubahan. Siklus ini membantu untuk menjawab pertanyaan-pertanyaan seperti:

a. Apa yang bisa kita harapkan dengan mengambil tindakan melakukan upaya upaya perubahan?

b. Seperti apa proses transformasi yang akan dilakukan?

c. Bagaimana akan dikembangkan?

d. Apa hambatan-hambatan selama proses perubahan?

Ketika kita berbicara mengenai siklus berarti ada tahapan yang harus dilampaui dan berulang. Tahapannya adalah: 1 . menentukan target, 2 . menentukan tujuan atau membuat rencana, 3. berinisiatif melakukan tindakan, 4 . membuat perubahan terjadi, 5. menyeimbangkan kembali untuk mengakomodasi perubahan, 6. melakukan proses pembelajaran, 7. menuju ke siklus berikutnya.

Menurut Goldberg dan Sifonis (1994), manajer mengelola organisasi tidak hanya untuk bisa hidup dalam jangka pendek, tetapi juga merencanakan dan membangunnya untuk masa yang akan datang. Mereka menyebutnya sebagai perencanaan dinamis, yaitu perencanaan yang aktif dan berubah yang disesuaikan dengan kondisi organisasi. Ini adalah proses yang membutuhkan waktu dan 
mengubah bagaimana manajemen berpikir dan bertindak. Perencanaan dinamis sebagai pendekatan manajemen strategik.

Di organisasi-organisasi besar, perencanaan ini dapat bekerja baik ketika diaplikasikan pada fungsi operasional, seperti pemasaran ataupun unit bisnis lainnya. Perencanaan ini juga bisa digunakan sebagai dasar evaluasi untuk melihat apakah prosedur baru dapat ditambahkan agar proses yang ada lebih baik. Proses perencanaan dinamis terdiri dari beberapa aktivitas, yaitu:

1. Identifikasi masalah.

Langkah ini memerlukan analisis ekternal, yaitu evaluasi dorongandorongan dari luar yang berdampak langsung pada organisasi, serta analisis internal dengan menilai kekuatan-kekuatan organisasi dan orang-orangnya.

2. Mencari solusi.

Langkah ini merupakan persiapan untuk menentukan apa faktor-faktor kunci kesuksesan, seberapa baik akan memenuhinya, dan dimana akan melakukan perbaikan. Organisasi bisa memilih opsi yang bisa menentukan kemungkinan pertumbuhan dengan kekuatan dan kompetensi inti yang ada.

3. Analisis solusi.

Analisis ini dilakukan untuk melihat dampak setiap opsi yang dipilih terhadap strategi dan struktur bisnis maupun teknologi.

\section{Melaksanakan solusi.}

Manajer mengembangkan grand strategy, memilih dari opsi yang telah dianalisis dan mengembangkan rencana untuk mencapainya. Manajer mengelola perubahan dengan membantu karyawan beradaptasi dengan perubahan yang harus dibuat untuk mengimplementasikan arah baru yang telah dipilih.

\section{Mengembangkan "Kesiapan" untuk Melakukan Perencanaan}

Semua organisasi dapat memperoleh manfaat ketika para pimpinan membuat persiapan untuk proses perencanaan formal dan menerima setiap hasil perubahan. Proses ini penting, khususnya bagi organisasi nonprofit karena staf operasional biasanya berpartisipasi dalam perencanaan dan tidak siap memahami atau menerima perubahan.

Ada dua tahap untuk mencapai kesiapan organisasi, yaitu mengidentifikasi setiap individu dan kelompok yang harus mengubah cara mereka bekerja dan menilai kemauan atau keinginan orang-orang untuk melakukan perubahan. Untuk menilai kesiapan dapat dilihat dari dua prinsip dasar. Pertama, kesiapan emosional, yaitu tingkatan anggota organisasi mau dan mampu hidup dalam ketidakpastian 
dan meninggalkan status quo. Level kedua adalah mengukur atribut-atribut yang dimiliki organisasi, termasuk struktur pengambilan keputusan yang pluralistik, legitimasi penyimpangan, dan struktur kekuasaan yang solid. Kesiapan ini sebagai sesuatu yang mengawali proses perencanaan yang akan dilakukan.

Ada tujuh komponen yang dapat mempengaruhi pengembangan kesiapan perencanaan (Gibson and Mazur, 1995). Pendekatan untuk mengatasi problem juga diperlukan untuk mencapai hasil yang diinginkan. Beberapa komponen|kesiapan dan'pendekatan yang perlu dilakukan dapat dilihat dalam tabel 1 .

Tabel 1.

Komponen-Komponen Kesiapan Perencanaan

\begin{tabular}{|c|c|c|}
\hline Komponen & Pendekatan & Hasil yang diinginkan \\
\hline $\begin{array}{l}\text { Menyetujui } \\
\text { adanya } \\
\text { ketidakpastian }\end{array}$ & $\begin{array}{l}\text { Menilai level kepuasan dan } \\
\text { risiko yang dipersepsikan oleh } \\
\text { setiap individu. } \\
\text { Mengukur persepsi kebutuhan } \\
\text { untuk berubah dan kemampuan } \\
\text { untuk melakukan perubahan. }\end{array}$ & $\begin{array}{l}\text { Memahami seberapa jauh } \\
\text { keinginan dan } \\
\text { kemampuan untuk } \\
\text { membuat rencana dan } \\
\text { mengimplementasikan } \\
\text { strategi. }\end{array}$ \\
\hline $\begin{array}{l}\text { Mengurangi rasa } \\
\text { takut }\end{array}$ & $\begin{array}{l}\text { Melalui training dan diskusi, } \\
\text { membantu anggota organisasi } \\
\text { memahami rasa takut dan } \\
\text { kemungkinan kehilangan. } \\
\text { Memberi dukungan selama } \\
\text { masa transisi. }\end{array}$ & $\begin{array}{l}\text { Perhatian yang lebih } \\
\text { besar dan memahami } \\
\text { issues pribadi dan politis } \\
\text { dalam transisi organisasi. }\end{array}$ \\
\hline $\begin{array}{l}\text { Memastikan } \\
\text { pentingnya } \\
\text { pembelajaran }\end{array}$ & $\begin{array}{l}\text { Mengkomunikasikan sesering } \\
\text { mungkin mengenai realitas } \\
\text { ekonomi sekarang dan alasan } \\
\text { kebutuhan untuk berubah. } \\
\text { Memberi kebebasan untuk trial } \\
\text { and error dan menstimulasi } \\
\text { pembelajaran. }\end{array}$ & $\begin{array}{l}\text { Lingkungan yang aman } \\
\text { bagi karyawan untuk } \\
\text { mempelajari ketrampilan } \\
\text { baru melalui trial and } \\
\text { error. }\end{array}$ \\
\hline $\begin{array}{l}\text { Memahami } \\
\text { proses strategic } \\
\text { planning }\end{array}$ & $\begin{array}{l}\text { Mengajari partisipan mengenai } \\
\text { proses perencanaan. }\end{array}$ & $\begin{array}{l}\text { Kemampuan untuk } \\
\text { mencapai tujuan } \\
\text { strategic planning. }\end{array}$ \\
\hline $\begin{array}{l}\text { Memerlukan } \\
\text { sumber-sumber } \\
\text { ketrampilan } \\
\text { yang memadai }\end{array}$ & $\begin{array}{l}\text { Mengidentifikasi individu dan } \\
\text { kelompok dengan ketrampilan } \\
\text { yang dibutuhkan dari dalam } \\
\text { dan dari luar organisasi. }\end{array}$ & $\begin{array}{l}\text { Menyediakan } \\
\text { pengetahuan yang } \\
\text { dibutuhkan pada waktu } \\
\text { yang tepat. } \\
\text { Menyediakan motivasi }\end{array}$ \\
\hline
\end{tabular}




\begin{tabular}{|l|l|l|}
\hline & & $\begin{array}{l}\text { dan tantangan yang lebih } \\
\text { besar bagi karyawan yang } \\
\text { terlibat dalam } \\
\text { perencanaan. }\end{array}$ \\
\hline $\begin{array}{l}\text { Mengelola } \\
\text { pergeseran } \\
\text { budaya }\end{array}$ & $\begin{array}{l}\text { Menilai sukses dan kegagalan } \\
\text { masa lalu. } \\
\text { Mencoba dengan ide-ide baru. } \\
\text { Membuat keyakinan dan nilai- } \\
\text { nilai organisasi eksplisit. } \\
\text { Menghargai kreatifitas dan } \\
\text { fleksibilitas. }\end{array}$ & $\begin{array}{l}\text { Pengetahuan mengenai } \\
\text { kultur yang berlangsung. } \\
\text { Penerimaan yang lebih } \\
\text { besar atas perubahan } \\
\text { strategik. }\end{array}$ \\
\hline $\begin{array}{l}\text { Mengembangkan } \\
\text { pengetahuan } \\
\text { organisasional }\end{array}$ & $\begin{array}{l}\text { Leader harus membangun } \\
\text { pengetahuan mengenai realitas } \\
\text { saat ini dan yang akan datang. } \\
\text { Membangun pemahaman setiap } \\
\text { orang mengenai tantangan } \\
\text { pribadi, profesi, dan organisasi } \\
\text { melalui pertemuan-pertemuan } \\
\text { organisasi. }\end{array}$ & $\begin{array}{l}\text { Level komitmen yang } \\
\text { lebih besar dan kemauan } \\
\text { untuk merencanakan. }\end{array}$ \\
Wawasan yang \\
terdistribusi.
\end{tabular}

\section{Komponen 1: Menyetujui adanya ketidakpastian.}

Salah satu respon yang paling umum oleh anggota organisasi yang terlibat dalam perencanaan strategik adalah kondisi yang akan datang yang tidak pasti. Ketidakpastian memang menakuṭan bagi setiap orang, tetapi mereka harus mau untuk hidup dengan ketidakpastian dan meninggalkan status quo untuk mengimplementasikan perubahan.

Pengetahuan mengenai keinginan kolektif organisasi dapat membantu leader menentukan bagaimana dapat berhasil dengan adanya perubahan. Seseorang yang mempunyai level kepuasan rendah dengan status quo dan juga mempunyai persepsi risiko rendah mempunyai keuntungan dengan adanya perubahan, malah melihat suatu manfaat dengan adanya perubahan. Sebaliknya, seseorang yang puas dengan status quo dan melihat risiko pribadi yang tinggi akan cenderung menentang perubahan.

\section{Komponen 2: Mengurangi rasa takut.}

Ketakutan sering menjadi akar sebab resistensi untuk berubah. Pimpinan dapat menggunakan strategi untuk membantu anggota organisasi menghilangkan rasa takut dan mengatasi tahapan transisi emosional. Manajer semestinya memprediksi dan menerima tanda-tanda keluhan emosional. Kesiapan perencanaan 
ini dapat ditingkatkan dengan membantu anggota organisasi dapat melampaui tahapan akan kehilangan.

\section{Komponen 3. Memastikan pentingnya pembelajaran.}

Pembelajaran sangat penting untuk mewujudkan dan menjaga keunggulan bersaing dan organisasi yang belajar dengan baik akan lebih fleksibel dan sukses. Manajemen harus menyelenggarakan iklim belajar karena perhatian terhadap kébutuhan akan perubahan tidaklah cukup untuk membuat orang belajar cara baru atau mengubah perilaku. Setiap anggota perlu mengakui bahwa cara lama tidak akan sesuai lagi. Pimpinan harus mengadakan komunikasi mengenai realitas ekonomi yang dihadápi organisasi.

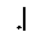

\section{Komponen 4. Memahami proses perencanaan strategik}

Setiap partisipan dalam perencanaan harus mengetahui proses perencanaan strategik. Partisipan dituntut setuju dengan isu konseptual. Pergeseran ini sulit untuk untuk dicapai karena yang dipikirkan terbatas pada isu operasional. Agar perencanaan efektif, pelatihan dibutuhkan untuk mengembangkan apresiasi pada pemikiran strategik yang memfokuskan pada isu makro yang sangat penting bagi kesuksesan jangka panjang.

\section{Komponen 5. Memerlukan keahlian yang cukup dan sumber daya.}

Pengetahuan dan keahlian diperlukan untuk perencanaan yang "efektif, baik proses dan implementasinya. Ada memang beberapa orang dalam organisasi yang memiliki pengalaman atau pengetahuan yang tidak akan bernilai dalam proses. Organisasi perlu melihat dari pengalaman ini. Dari contoh ini memberi tantangan baru bagi karyawan dan ini memotivasi mereka. Bantuan dari luar organisasi diperlukan untuk mengembangkan keahlian karyawan. Sumber daya dari luar ini dapat bertindak sbagai coach, fasilitator, atau sebagai konsultan.

\section{Komponen 6. Mengelola pergeseran kultur.}

Kesiapan perencanaan meningkat ketika manajer mempertimbangkan nilainilai dan keyakinan untuk mengarahkan kinerja organisasi. Perubahan yang dilakukan melalui perencanaan strategik akan lebih siap diterima jika anggota organisasi memahami bagaimana ide-ide baru membantu organisasi. Semakin besar jarak antara kultur yang sudah ada dengan perubahan yang diinginkan, semakin sulit perubahan dapat diimplementasikan.

Mengelola pergeseran perubahan berarti memahami karakteristik perubahan yang diinginkan dan melakukan aktivitas-aktivitas untuk membantu pergeseran ini terjadi. Organisasi bereksperimen dengan ide-ide banu dan mau 
gagal untuk dapat memahami apa yang dapat berhasil dan tidak berhasil dalam organisasi.

\section{Komponen 7. Mengembangkan pengetahuan organisasi.}

$\cdots$ Kelangsungan hidup organisasi memerlukan anggota organisasi yang dapat mengembangkan keahlian baru dan fleksibilitas. Karyawan tidak akan dapat membuat keputusan yang baik bagaimana merespon kecuali mereka mengembangkan pengetahuan yang tinggi mengenai kondisi sekarang dan yang akan datang yang dihadapi organisasi. Mengembangkan pengetahuan merupakan tanggung jawab pimpinan dan menciptakan suasana siap untuk bertindak.

Karyawan perlu mempunyai pengetahuan mengenai keyakinan dan nilainilai yang mengarahkan organisasi lebih baik, mengetahui sukses dan kegagalan di masa lalu, realitas persaingan, dan tuntutan customer, investor, dan pihak lain. Pengetahuan akan muncul jika ada nilai-nilai belajar. Mencapai pengetahuan organisasional memerlukan interaksi tingkat tinggi antara pimpinan dan karyawan melalui pertemuan-pertemuan sesering mungkin dan membuka terhadap pertanyaan-pertanyaan sulit. Pertemuan bisa diselenggarakan kelompok demi kelompok sampai seluruh karyawan mendengarkan diskusi mengenai realitas yang dihadapi organisasi.

\section{Implementasi Strategi}

Studi menunjukkan bahwa ada beberapa hal penting bagi kesuksesan implementasi proses perubahan organisasi (McLagan, 2002). Usaha-usaha pimpinan untuk mengubah masih merupakan upaya trial \& error. Pelajaran penting yang bisa ditarik dari studi yang dilakukan dalam implementasi perubahan organisasi dan keberlanjutannya adalah yakin bahwa perubahan akan menambah nilai, menyesuaikan antara proses perubahan dengan tantangannya, menyediakan dukungan manajemen, menyiapkan sistem untuk perubahan, dan membantu orangorang untuk terlibat.

Ada beberapa hal yang perlu diperhatikan oleh seorang pimpinan atas dirinya. Pimpinan dituntut memiliki keterlibatan tinggi dan mengambil keputusan, juga memberi contoh baik yang dapat dipelajari oleh anggota organisasi. Semua ini sangat penting bagi implementasi strategi (Hrebiniak, 1990; Nelson and Quick, 1997).

\section{Memotivasi perencanaan.}

Manajer puncak terlibat dalam proses perencanaan perusahaan.Peran partisipasi dan penerimaan adalah faktor penting perencanaan. Validitas dan kelayakan data penting selama proses. Perhatian manajer puncak termasuk di 
antaranya bertanya dengan pertanyaan yang harus dijawab dan mendorong staf untuk mengumpulkan informasi yang benar untuk menjawab pertanyaanpertanyaan tersebut. Manajer puncak harus memotivasi perencanaan pada level perusahaan dan level operasional. Termasuk didalamnya interaksi dan komunikasi antara korporat, divisi, perusahaan atau level SBU untuk meyakinkan adanya konsistensi. Oleh karenanya, dibutuhkan konsistensi dan integrasi semua level dan tipe perencanaan strategik.

\section{Mempertimbangkan dengan baik peran struktur.}

Struktur harus dapat mendukung strategi. Kondisi persaingan, struktur industri, dan tipe pertumbuhan mempengaruhi pilihan organisasi. Pada level korporat, strategi diversifikasi portofolio harus mempertimbangkan hubungan antara produk, pasar, teknologi, dan sinergi potensial antar perusahaan dan unit operasi. Pada level perusahaan, perlu hati-hati dalam menetapkan struktur organisasi agar konsistensi dengan korporasi tetap terjaga.

\section{Mengetahui apa insentif yang mendukung.}

Perencanaan strategik dan tujuan harus terintegrasi dengan tujuan dan aktivitas operasi. Hasil yang yang diharapkan harus didukung dengan insentif yang jelas. Implementasi strategi sering gagal karena sistem insentif perusahaan. Cara untuk menentukan insentif adalah: menggunakan tujuan yang terukur, mengkaitkan insentif dengan kinerja, dan memonitor konsistensi. Outcome kinerja tidak boleh ambigu. Setiap orang di setiap level dalam organisasi tahu benar bagaimana kinerja yang baik. Hubungan antara kinerja dengan penghargaan juga harus jelas. Setiap orang tahu apa yang diharapkan daripadanya dan apa yang mereka harapkan dari perusahaan.

\section{9. 'Mendorong untuk memonitor pasar.}

Manajer puncak menggunakan waktunya lebih banyak untuk perencanaan strategik daripada pengendalian. Sistem monitor ini akan sulit terutama karena kondisi ketidakpastian, heterogenitas pasar, kompleksitas tugas, dan situasi yang akan muncul dalam perencanaan jangka panjang.

\section{Pelaksanaan kepemimpinan.}

Jika manajer puncak menginginkan menciptakan kultur, dia harus berani mengambil risiko. Manajer dibolehkan membuat kesalahan. Ada toleransi dari semua risiko yang muncul dari kesalahan, kecuali karena kebodohan, kecerobohan, atau kepribadian yang buruk orang yang mengambil risiko tersebut. Untuk mengurangi risiko, informasi dari level di bawahnya sangat diperlukan. Manajer puncak perlu menjelaskan kesuksesan dan kekurangan. Manajer harus selalu 
memperhatikan stakeholders penting yang mendukung proses manajemen strategik.

\section{Peran Pimpinan dalam Proses Perubahan}

- Peran pimpinan sangat jelas diperlukan dalam sebuah proses perubahan. Ada 3 kategori aktivitas luas seorang pemimpin dalam masa perubahan ini. Kategori yang dimaksud adalah: menciptakan situasi dan lingkungan, memperhatikan pada sistem, dan mengembangkan organisasi (Yoongblood, 1997).

\section{Menciptakan situasi dan lingkungan.}

Pimpinan perlu kreatif untuk menentukan identitas. Identitas organisasi dikembangkan melalui tujuan, prinsip-prinsip, strategi, dan kultur, yang semuanya itu dikemas dalam sebuah visi organisasi. Sekarang banyak organisasi telah mendefinisikan pernyataan visi mereka. Mereka memiliki komitmen waktu, sumberdaya, dan uang untuk secara hati-hati mewujudkan setiap pernyataan dalam visinya. Visi itu sudah dicetak, dibingkai, dan digantungkan di setiap dinding kantor. Tetapi jika kita bertanya kepada setiap karyawan mengenai visi organisasi dan bagaimana visi tersebut mempengaruhi pekerjaannya sehari-hari, banyak dari mereka tidak bisa menjawab demikian juga para pimpinannya.

a. Klarifikasi visi.

Pimpinan memperjelas visi kepada seluruh anggota melalui dialog yang intensif dan partisipasi aktif anggota. Karyawan didorong untuk mengembangkan dan mempertahankan visi dengan fokus pada tujuan jangka panjang dan jangka pendek organisasi.

b. Memperkaya kultur.

Sistem yang dirancang memupuk pada tindakan self-directed setiap karyawan. Caranya adalah menjadikan karyawan dapat beroperasi dengan aturan sedikit dan tetap menciptakan hasil yang produktif dengan kultur yang kuat.

c. Mengembangkan konfigurasi.

Karyawan terbaik pun tidak bisa menciptakan kinerja organisasi jika seluruh elemen organisasi tidak pada posisinya. Koherensi dalam

$\therefore$ organisasi terjadi ketika orang-orang dan disain organisasi tersusun "menyatu dengan tujuan, strategi, dan prinsip.

d. Memupuk pemahaman.

Pimpinan membantu organisasi untuk memahami dan menginterpretasikan informasi dan peristiwa sesuai visi organisasi. Seringkali anggota dihadapkan pada data yang ambigu, kontradiksi, dan membingungkan, sehingga pimpinan bisa mengklarifikasi "gangguan" ini dan mengolahnya 
menjadi informasi yang berarti. Orang-orang di dalam organisasi bekerja dengan situasi yang berbeda dan pimpinan perlu menemukan bahasa yang disesuaikan dengan kondisi fisik maupun psikologis mereka. Pesan bagi para engineer tidak bisa disampaikan secara sama dengan pesan yang disampaikan kepada para pekerja pabrik.

\section{Memperhatikan sistem.}

Pimpinan tidak menciptakan stabilitas dalam organisasi, tetapi sebaliknya.

Berapa tindakan yang bisa dilakukan adalah: menciptakan tujuan-tujuan persuasif, meyakinkan arus informasi yang akurat, menawarkan keberbedaan pendapat, dan mengubah kekecewaan karyawan menjadi tindakan yang lebih kréatif.

\section{Mengembangkan organisasi.}

Pimpinan memiliki tanggung jawab untuk membantu organisasi dalam menciptakan kondisi sebagai berikut:

a. Pimpinan secara kontinyu menyatakan bahwa keberhasilan organisasi milik anggota. Pimpinan mengkomunikasikan pentingnya komitmen, usaha, dan percaya diri untuk menciptakan kondisi agar setiap orang merasa memiliki pekerjaan dan organisasi.

b. Pimpinan mencari kesempatan untuk membantu karyawan dan kelompok untuk berhubungan satu sama lain. Pimpinan mendorong adanya hubungan ' jangka panjang yang sehat dan secara aktif menyampaikan pentingnya ' kolaborasi, kerja sama, dan pengembangan bersama.

c. 'Pimpinan mendorong pembelajaran terjadi dalam organisasi, memacu berinovasi di seluruh organisasi. Pimpinan perlu memahami bahwa belajar adalah proses trial \& error, oleh karenanya perlu memahami pengambilan risiko dan dan toleransi atas kesalahan dan kegagalan. Pembelajaran juga , berarti proses memperluas kesadaran setiap orang atas pengetahuan dunia. Pimpinan perlu meyakinkan adanya keberbedaan ide maupun sudut pandang berpikir.

Pimpinan memanfaatkan spirit setiap orang. Organisasi adalah kumpulan orang-orang. Mereka ibarat taman dengan harapan, aspirasi, dan keyakinan yang ditanamkan agar tumbuh dan bisa menghasilkan. Orang menghirup udara kehidupan di dalam organisasi melalui komitmen dan energi positifnya. Dengan memberikan lingkungan atau suasana yang tepat, orang akan self-organized untuk menciptakan organisasi yang dinamis, berkembang, dan sukses. Mereka akan melakukan hal itu dalam situasi yang baik maupun buruk. 


\section{Penutup}

Perubahan organisasi sebagai bentuk pengembangan organisasi masih akan berlanjut sebagai suatu ilmu dan seni. Proses trial and error masih merupakan usaha-usaha manajer untuk menghadapi isu perubahan. Identifikasi forces dan hambatan-hambatan akan perubahan organisasi, menentukan rencana perubahan, dan mempersiapkan anggota organisasi untuk bisa merespon tuntutan lingkungan merupakan pekerjaan manajer yang tidak mudah.

Peran pimpinan organisasi sangat besar dalam proses perencanaan dan implementasi perubahan organisasi. Dengan berbagai power yang dimiliki, pimpinan bisa mewujudkan proses perubahan yang dikendaki dengan hasil seperti yang diharapkan. (Guiterrez and Kleiner, 1995). Juga, pimpinan bisa menciptakan lingkungan yang bisa memicu perubahan, bisa menjadi contoh dalam proses perubahaan, dan bisa menciptakan keterlibatan anggota organisasinya dalam proses perubahan organisasi. 


\section{DAFTAR PUSTAKA}

Bonvilian, Gary. 1997. "Managing the Messages of Change: Lessons from the Field", Industrial Management. Jan/Feb:20-25.

Gibson, C Kendrik and Denise A. Mazur. 1995. "Preparing for The Strategic Planning Process Helps Ensure Implementation Success", Health Care Strategic Management. January:14-17.

Goldberg, Beverly and John G. Sifonis. 1994. "Planning for Chaos", Executive Exellence. March: 8-9.

Guiterrez, Kenneth A. and Brian H. Kleiner. 1995. "Enhancing Personal Power In Organizations", Agency Sales Magazine. March: 52-56.

Head, Thomas C. 2006. "Strategic Organization Development: A Failure of True Organization Development", Organization Development Journal. Winter: 21-28.

Heifetz, Michael and Stan Halle. 1996. "Leading Change, Overcoming Chaos Making Change Succeed in Your Organization", Hosp Materiel Manage $Q: 17-27$.

Hopen, Deborah. 2004. "Consequences and Changing Behaviors", The Journal for Quality \& Participation. Spring:15-23.

Hrebiniak, Lawrence G. 1990. "Implementing Strategy",Chief Executive. April: 74-77.

McLagan, Patricia A. 2002. "Success with Change", $T \& D$. December: 44-52.

Nelson, Debra L and James Campbell Quick. 1997. Organizational Behavior: Foundations, Realities, and Challenges, West Publishing Company.

Stoner, James A.F., R. Edward Freeman, and Daniel A. Gilbert, Jr. 1995. Management, 6ed. Prentice-Hall.

Yoongblood, Mark D. 1997, "Leadership at the Edge of Chaos: From Control to Creativity", Strategy and Leadership.:8-14. 
